\title{
Seagrass (Zostera marina) promotes nitrification potential and selects specific ammonia oxidizers in coastal sediments
}

\author{
Xianbiao Lin $^{1,2} \cdot$ Pengfei Zheng ${ }^{3,4} \cdot$ Songbao Zou ${ }^{3,4} \cdot$ Feifei Sun $^{3} \cdot$ Xiaoli Zhang $^{3,5}$ (D) Jun Gong ${ }^{1,2}$ \\ Received: 19 February 2021 / Accepted: 12 April 2021 \\ (C) The Author(s), under exclusive licence to Springer-Verlag GmbH Germany, part of Springer Nature 2021
}

\begin{abstract}
Purpose Seagrasses accelerate sedimentation, release oxygen and organic matter through their roots, and compete with ammonia oxidizers for ammonia/ammonium in surface sediments and overlying water, all of which can influence benthic aerobic nitrification. To understand the effects of seagrass vegetation on benthic nitrification, the heterogeneity of nitrification activities and functional microbial communities between seagrass-vegetated and adjacent bare sediments was investigated.

Materials and methods Surface $(0-5 \mathrm{~cm})$ sediments were sampled from a Zostera marina-colonized coastal lagoon in northern China. The potential nitrification rates (PNR) and relative contributions of ammonia-oxidizing bacteria $\left(\mathrm{PNR}_{\mathrm{aob}}\right)$ and ammoniaoxidizing archaea $\left(\mathrm{PNR}_{\mathrm{aoa}}\right)$ were determined based on the sediment slurry incubation with kanamycin inhibition method. The abundances and community compositions of ammonia-oxidizing bacteria (AOB) and ammonia-oxidizing archaea (AOA) were determined using qPCR, clone library, and high-throughput sequencing.

Results and discussion The total PNR $\left(\mathrm{PNR}_{\text {total }}\right)$ in the seagrass-colonized sediments were significant higher than those in the bare sediments $(P<0.05)$, to which $\mathrm{PNR}_{\mathrm{aob}}$ contributed 59.7\% and 55.8\% in vegetated and unvegetated sediments, respectively. The concentrations of chlorophyll $a$ and dissolved inorganic nitrogen were key factors determining benthic PNR. AOB outnumbered AOA by one order of magnitude by targeting amoA gene abundance, and no significant difference $(P>0.05)$ in amoA gene abundance and diversity was observed between the two habitats. Most AOB genotypes were affiliated to Nitrosomonas, of which NL7 was selectively enriched in the vegetated region, while $N$. cryotolerans prevailed in the bare. Two distinct AOA groups Crenarchaeota $1.1 \mathrm{~b}$ and Crenarchaeota 1.1a dominated in vegetated and unvegetated sediments, respectively. Dissolved oxygen of overlying water and TOC:TN of sediment significantly influenced AOB community, while AOA community was strongly driven by nitrate and metal iron in sediments.

Conclusions Seagrass vegetation substantially enhances nitrification potential and selects specific ammonia oxidizers in coastal sediments.
\end{abstract}

Keywords Seagrass meadow $\cdot$ Potential nitrification rates $\cdot$ Relative importance $\cdot$ Gene copy number $\cdot$ Specific lineage

\section{Introduction}

Seagrass meadows are highly productive ecosystems that provide significant ecosystem services, including invertebrate

Responsible editor: Hongbin Yin

Xiaoli Zhang

xlzhang@yic.ac.cn

Jun Gong

gongj27@mail.sysu.edu.cn

1 School of Marine Sciences, Sun Yat-Sen University, Zhuhai 519082, China

2 Southern Marine Science and Engineering Guangdong Laboratory (Zhuhai), Zhuhai 519000, China and fish habitat, sediment stabilization, wave attenuation, tourism and recreation, and carbon sequestration (Barbier et al. 2011). Through their high productivity, seagrass meadows perform as important nitrogen $(\mathrm{N})$ filters in coastal Key Laboratory of Coastal Environmental Processes and Ecological Remediation, Yantai Institute of Coastal Zone Research, Chinese Academy of Sciences, Yantai 264003, China

4 University of Chinese Academy of Sciences, Beijing 100085, China

5 Center for Ocean Mega-Science, Chinese Academy of Sciences, Qingdao 266071, China 
environments: seagrasses assimilate large amounts of $\mathrm{N}$ into their biomasses; seagrass roots exude oxygen and labile carbon into sediments, which stimulate coupled nitrification-denitrification, leading to $\mathrm{N}$ removal through the microbial transformation of ammonium $\left(\mathrm{NH}_{4}{ }^{+}\right.$) into $\mathrm{N}_{2}$ (Zarnoch et al. 2017; Aoki et al. 2020). However, global seagrass meadows are declining rapidly, and $\sim 29 \%$ of the recorded seagrass meadows had declined from 1879 to 2009 (Waycott et al. 2009). The degradation of seagrass meadows is to a great extent attributed to $\mathrm{N}$ overloading induced eutrophication (Hauxwell et al. 2003; Waycott et al. 2009). Therefore, understanding $\mathrm{N}$ transformation processes and fluxes in seagrass meadows is of vital importance and extremely urgent to manage, protect, and restore the seagrass ecosystem.

Nitrification is central to $\mathrm{N}$ biogeochemical cycle, connecting $\mathrm{N}$ fixation and $\mathrm{N}$ losses of environments. Nitrification is traditionally considered a two-step oxidation process, of which ammonia oxidation is the first and rate-limiting step and is performed by two distinct ammonia oxidizers, ammonia-oxidizing bacteria (AOB) and ammonia-oxidizing archaea (AOA), as well as nitrite oxidation by nitrite-oxidizing bacteria (NOB). Recent findings show that a subset of bacteria affiliated with Nitrospira, a genus known for its importance in nitrite oxidation, are capable of complete ammonia oxidation (comammox) to nitrate (van Kessel et al. 2015). However, there is so far no evidence supporting the existence of comammox in marine environments (Sun et al. 2020). Based on previous studies, AOA has stronger affinities for ammonia and oxygen, and is more energy efficient than AOB (MartensHabbena et al. 2009; Schleper 2010; Stahl and de la Torre 2012). Furthermore, the lack of cytochrome $c$ proteins and the existence of numerous genes encoding copper-containing proteins in AOA suggest a different electron transport mechanism from that of the highly iron-heme-dependent AOB (Stahl and de la Torre 2012). All of these cause their different ecological niches and contributions to ammonia oxidation in various environments.

Several previous studies have concerned the influence of seagrass colonization on sediment nitrification. In the Zostera marina bed of Chesapeake Bay, Caffrey and Kemp (1990) found higher potential nitrification rates (PNR) in the vegetated sediments than in the unvegetated sediments, and the release of $\mathrm{O}_{2}$ from seagrass roots and rhizomes was thought to enhance the nitrification activity. Conversely, Ottosen et al. (1999) recorded much lower nitrification rates in $Z$. marina sediments compared to the bare marine sediments in the Limfjorden Estuary, and they suggested that high organic loading and sulfate reduction activity in the vegetated sediments could impede the nitrification in this estuary with patchy populations of $Z$. marina. These conflicting results implied that the sediment nitrification activity in seagrass systems was controlled by the growing state of seagrass and local habitat conditions including organic loading as well as sediment $\mathrm{N}$ and sulfide levels. To distinguish the individual contribution of AOA and AOB, some group specific inhibitors such as antibiotic kanamycin and ampicillin (both suppressing bacterial protein synthesis) (Taylor et al. 2010; Zheng et al. 2014; He et al. 2018) and N1-guanyl-1,7-diaminoheptane (GC7) (causing archaeal growth arrest) (Berg et al. 2015) were used. Zheng et al. (2014) found that AOA contributed to the majority of ammonia oxidation in the Yangtze estuarine sediments. In the surface sediments of Rushan Bay, an important mariculture base, AOB played more in ammonia oxidation in summer, while AOA dominated in winter (He et al. 2018). Temperature, dissolved oxygen (DO), inorganic nitrogen, and chlorophyll $a(\mathrm{Chl}-a)$ appeared to impact the relative importance of AOA and AOB (He et al. 2018). To date, little is known about the individual contribution of AOA and AOB in seagrass meadows, although some studies have evaluated their relative contributions by comparing amoA gene abundance in the ecosystem (Ando et al. 2009; Ling et al. 2018).

Plant colonization has been suggested to affect the abundance and community structure of benthic AOA and $\mathrm{AOB}$ and further impact nitrification activities and their contributions (Li et al. 2011; Wang et al. 2015; Zhang et al. 2015a). In the oligotrophic coral reef seagrass (Thalassia hemprichii) meadow, AOB dominated in ammonia oxidizers and all of AOB genotypes were affiliated to Nitrosomonadales (Ling et al. 2018). In the N-depleted $Z$. marina sands, the abundance of AOA was equal to AOB, and Nitrosospira was prevalent in the AOB community (Ando et al. 2009). Regardless, the above-mentioned investigations just focused on the oligotrophic seagrass systems, and few studies so far involve the characteristics of ammonia oxidizer communities in the fertile seagrass systems, even though trophic status can regulate the competition for $\mathrm{NH}_{4}{ }^{+}$between ammonia oxidizers and plants as we known (Caffrey and Kemp 1990; Rysgaard et al. 1996).

In this study, the potential nitrification rates (PNR), the individual contribution of $\mathrm{AOA}$ and $\mathrm{AOB}$, and the abundances and compositions of AOA and AOB community in surface sediments of a temperate fertile $Z$. marina meadow were investigated concomitantly. The objectives were to evaluate the relative importance of AOA and AOB to ammonia oxidation, to test whether there are variation in functions, abundance, and diversities of AOA and AOB between seagrass vegetated and the adjacent bare sediments, and to know the major factors determining the variation of the potential nitrification and the niche differentiation of ammonia-oxidizing prokaryotes in the seagrass meadow ecosystem. 


\section{Materials and methods}

\subsection{Description of sites and sampling}

Zostera marina is one of the most widely distributed seagrass species among temperate coasts in both hemispheres. The study area was located in a lagoon, to the southwest of Rongcheng Bay, Shandong Peninsula, northern China (N37 $20^{\prime}$ 58', E122 34' 48"), where Z. marina is prevalent. Sampling was made in May of 2013 as previously described (Sun et al. 2015). In brief, the surface $(0-5 \mathrm{~cm})$ sediments were collected in five vegetated sites (V1 to V5) and another five unvegetated sites (U1 to U5, without seagrass colonization) with a custom-made corer (inner diameter, $7 \mathrm{~cm}$ ) during the lower tide period, when the water depths were approximately $20 \mathrm{~cm}$. The vegetated sediments were collected from the seagrass rhizospheres, whereas the unvegetated sediments were obtained from the bare regions at a distance of approximately 20 to $40 \mathrm{~m}$ from the seagrass-covered region. The subsamples were stored in $4{ }^{\circ} \mathrm{C}$ for determining the potential nitrification rates (PNR), or stored at $-80^{\circ} \mathrm{C}$ for characterizing sediment physicochemical parameters and microbial communities.

\subsection{Determination of environmental parameters}

All of the environmental parameters have been reported elsewhere (Sun et al. 2015). These included temperature, salinity, concentrations of DO and Chl- $a$ in the overlying water, the median grain size of sediments (GS), total contents of organic carbon (TOC) and nitrogen (TN), and metal levels (including $\mathrm{Pb}, \mathrm{Cr}, \mathrm{Mn}, \mathrm{Fe}, \mathrm{Co}, \mathrm{Ni}, \mathrm{Cu}, \mathrm{Zn}, \mathrm{As}$, and $\mathrm{Cd}$ ) in the sediments, concentrations of dissolved inorganic nitrogen (DIN) and $\mathrm{NH}_{4}{ }^{+}, \mathrm{NO}_{2}{ }^{-}$, and $\mathrm{NO}_{3}{ }^{-}$species, and soluble reactive phosphate $\left(\mathrm{PO}_{4}{ }^{3-}\right)$ in the pore waters. Overall, the Chl- $a$ concentrations were significantly higher in the vegetated sites $(12.05$ $\left.\pm 0.1 \mu \mathrm{g} \mathrm{L}^{-1}\right)$ than those in the unvegetated sites $(5.03 \pm 0.14 \mu \mathrm{g}$ $\left.\mathrm{L}^{-1}\right)$. Seagrass promoted particle sedimentation, resulting in finer sediments and higher concentrations of various metals in the vegetated sites. In addition, the ratio of TOC:TN was significantly lower in the vegetated sediments $(6.58 \pm 0.83)$ compared with unvegetated sediments $(11.34 \pm 0.6)$. The sediments colonized by the seagrass had a mean $\mathrm{NH}_{4}{ }^{+}$concentration of $410.56 \pm 2.12 \mu \mathrm{M}$, which was significantly lower than that in the unvegetated sites $(1048.56 \pm 3.99 \mu \mathrm{M})$. Other parameters were not significantly different between these two types of sediment (Table S1).

\subsection{Potential nitrification rates}

The PNR was estimated within a week after sampling using the sediment slurry incubation method (Caffrey and Kemp 1990; Taylor et al. 2010; Zheng et al. 2014). In brief, the fresh sediment of $5.0 \mathrm{~g}$ was added into a Erlenmeyer flask $(150 \mathrm{~mL})$ containing $50 \mathrm{~mL}$ in situ overlying water. A concentrated $\mathrm{NH}_{4} \mathrm{Cl}$ solution $(100 \mathrm{mM})$ was supplemented into the slurry to a final concentration of $1 \mathrm{mM}$ and shaken at $120 \mathrm{r} \mathrm{min}^{-1}$ in the dark at the temperature measured in situ. During the period of incubation, subsamples $(10 \mathrm{~mL})$ were harvested at 0,24 , 48 , and $72 \mathrm{~h}$ and centrifuged. The supernatants were filtered through a $0.45-\mu \mathrm{m}$ pore size syringe filter, and immediately frozen for analyzing $\mathrm{NO}_{2}{ }^{-}$and $\mathrm{NO}_{3}{ }^{-}$concentrations using a nutrient AutoAnalyzer (Seal, Germany). The total PNR $\left(\mathrm{PNR}_{\text {total }}\right)$ contributed by both $\mathrm{AOA}$ and AOB was measured based on the increase of $\mathrm{NO}_{3}{ }^{-}$plus $\mathrm{NO}_{2}{ }^{-}$over time. To inhibit the activity of AOB, a kanamycin solution (final concentration of $800 \mu \mathrm{g} \mathrm{mL}^{-1}$ ) was added to the sediment slurry (Taylor et al. 2010, 2012). The nitrification rate detected in the presence of kanamycin was considered to be the contribution by AOA $\left(\mathrm{PNR}_{\mathrm{aoa}}\right)$, and the difference between $\mathrm{PNR}_{\text {total }}$ and $\mathrm{PNR}_{\text {aoa }}$, i.e., $\mathrm{PNR}_{\text {total }}-\mathrm{PNR}_{\text {aoa }}$, was attributed to $\mathrm{AOB}$ (i.e., $\mathrm{PNR}_{\mathrm{aob}}$ ). All assays were performed in triplicate.

\subsection{Quantitative real-time PCR (qPCR)}

DNA was extracted from sediment samples utilizing the FastDNA Spin Kit for soil (MP Biomedical, USA) under the guidance of the manufacturer's instructions. The amoA gene copy numbers of AOB and AOA were quantified using qPCR on a ABI 7500 Fast real-time PCR system (Applied Biosystems, USA). The primers for AOB amoA (amoA1F/ amoA2R) and AOA amoA (Arch-amoAF/Arch-amoAR) and PCR conditions followed Rotthauwe et al. (1997) and Francis et al. (2005), respectively. A $20 \mu \mathrm{L}$ reaction solution contained $10 \mu \mathrm{L}$ reagents in the SYBR green PCR/ carboxyX-rhodamine qPCR kit (Thermo, USA), $1 \mu \mathrm{L}$ of each primer at $10 \mu \mathrm{M}$, and $1 \mu \mathrm{L}$ of DNA template (5-10 ng). The data were retrieved at $72{ }^{\circ} \mathrm{C}$, and all of the reactions were finished with a melting curve from 60 to $95^{\circ} \mathrm{C}$ using increases of $0.5^{\circ} \mathrm{C}$. Standard DNA plasmids were prepared by cloning target gene fragments amplified from sediment samples, and the insertion of the correct gene fragments was confirmed by Sanger sequencing. The linear PCR amplicon standard was amplified from the circular plasmid. A 10-fold serial dilution $\left(10^{-1}\right.$ to $\left.10^{-8}\right)$ of the liner standard was used to generate standard curves. The efficiencies for all of the qPCR assays ranged from 91 to $103 \%$ and the correlation coefficients $\left(R^{2}\right)$ were greater than 0.98 . Controls without templates resulted in undetectable values for all of the samples.

\subsection{Community profiling and clone library construction for AOA}

The amoA gene fragments of AOA (ca. $635 \mathrm{bp}$ ) were amplified using the same primers used for qPCR. For community profiling of $\mathrm{AOA}$, terminal restriction fragment length 
polymorphism (T-RFLP) analysis was performed with 5carboxyfluorescein-labeled forward primer Arch-amoAF. The endonuclease HaeIII (Thermo, USA) was selected for digesting gene fragments. The fluorescently labeled terminal restriction fragments (T-RFs) were analyzed using a 3130XL genetic analyzer and GeneScan (v.2.1) software (Applied Biosystems, USA). The T-RFs shorter than $50 \mathrm{bp}$ or longer than $600 \mathrm{bp}$ were excluded from further analysis. The relative abundance of each T-RF was calculated as the ratio of the peak area of the T-RF to the total peak area of all T-RFs detected for a given sample. Minor peaks with a relative abundance of $<1 \%$ of the total were excluded.

Clone library and sequencing of archaeal amoA genes were conducted to obtain the phylogenetic information of the AOA. The PCR products from the sites V1-V5 and U1-U5 were pooled to generate two clone libraries. The amplicons were gel purified with a TIANGEN universal DNA purification kit (TIANGEN, China) and cloned into the pTZ57R/T vector using the InsTAclone PCR Cloning Kit (Thermo Fisher Scientific, USA). The inserts were verified directly from the cells using M13 vector-specific primers. Approximately 50 clones in each library were randomly selected for sequencing (Sangon, Shanghai, China). After identifying and removing chimeras using the Check Chimera program of the Ribosomal Database Project (Cole et al. 2014), the validated sequences were translated into amino acids using BioEdit (Hall 1999). A 3\% cutoff of sequence difference was applied to generate operational taxonomic units (OTUs) using DOTUR program (Schloss and Handelsman 2005). Rarefaction analysis for each clone library was performed. A maximum likelihood (ML) tree was built using the RaxML tool (v.8.0) (Stamatakis 2014) with the MTART+I+G+F model suggested by the ProtTest program (Darriba et al. 2011) and 1000 times bootstrap test.

\subsection{High-throughput sequencing and data processing for AOB}

High-throughput sequencing of $\mathrm{AOB}$ amoA gene fragments (ca. $450 \mathrm{bp}$ ) was carried out using pair read assembly strategies. All samples were amplified using 8-bp unique bar codes and primers amoA1F/amoA2R. The amplicons were purified and the libraries were generated and assessed, and finally sequenced on an Illumina MiSeq PE300 platform.

The raw fastq data were de-multiplexed, quality-filtered using QIIME (v.1.17) with the following criteria: (i) The 300-bp reads were truncated at any site receiving an average quality score $<20$ over a 10 -bp sliding window, discarding the truncated reads that were shorter than $50 \mathrm{bp}$; (ii) the barcodes were exactly matching, with 2 nucleotide mismatches maximum in the primer regions and no ambiguous characters; and (iii) only the sequences that overlap longer than $10 \mathrm{bp}$ were assembled according to their overlap sequence. The unassembled reads were discarded before subsequent analysis. Chimeric sequences were identified and removed using UCHIME and OTUs were clustered with a $97 \%$ similarity cutoff using UPARSE (v.7.1). Classification of AOB taxonomy was made based on the FunGene Repository (FGR) database (v.7.3, http://fungene.cme.msu.edu/) with a threshold of $E$-value $<0.00001$ (Fish et al. 2013) and the unclassified reads were removed prior to following analyses. We rarefied all sequences at the lowest number of high-quality sequences among all samples to generate alpha diversity estimators.

\subsection{Statistical analysis}

The T-RFLP profiling of AOA amoA gene was successful for all samples. However, two samples (V1 and U4) failed to be amplified for high-throughput sequencing of AOB amoA genes, thus excluded from subsequent analysis. The alpha diversity estimators (OTU richness, Simpson and Shannon indices) of amoA genes were calculated based on T-RFLP profiles (for AOA) and MiSeq sequencing (for AOB) using Mothur (Schloss et al. 2009). Student's $t$ tests (two-tailed) were performed to test the differences in PNR, relative contributions of AOA and AOB to ammonia oxidation, amoA gene copy numbers, diversity indices, and the proportions of individual genotypes of $\mathrm{AOB}$ between the vegetated and unvegetated sites. Pearson correlation coefficients $(r)$ were calculated to explore the relationships between (i) PNR and environmental variables; (ii) $a m o A$ gene abundance and environmental variables; (iii) the proportion of individual genotype of AOB and environmental variables; and (iv) PNR and amoA abundance or alpha diversity index. The normality of data was tested and log-transformed when necessary. All the analyses were performed using SPSS software (v. 20.0) for Windows (SPSS, Chicago, IL, USA).

The variations in $\mathrm{AOB}$ and $\mathrm{AOA}$ community structures were assessed on the basis of Bray-Curtis similarity matrices derived from high-throughput sequencing and T-RFLP data, respectively. To visualize, nonmetric multidimensional scaling (nMDS) ordination was performed using the PRIMER package (v.6) (Primer-E, UK). Analysis of similarity (ANOSIM) was performed to statistically test the hypothesis that the community structures of $\mathrm{AOB}$ and AOA were different between vegetated and unvegetated sites. Detrended correspondence analysis (DCA) revealed that the data exhibited a linear response to the environmental variables; therefore, redundancy analysis (RDA) was selected to explore the environment-biota relationships using the vegan package in $\mathrm{R}$.

\subsection{Accession numbers of nucleotide sequences}

The amoA gene sequences of AOA have been deposited in the GenBank database under accession numbers MN868313 to 
MN868411. The reads of MiSeq sequencing of AOB amoA gene are available under accession number PRJNA599046.

\section{Results}

\subsection{Total PNR and relative contributions of $A O A$ and AOB}

The $\mathrm{PNR}_{\text {total }}$ determined for the 10 sediment sites ranged from 0.15 to $1.0 \mu \mathrm{mol} \mathrm{g}^{-1}$ wet sediment $\mathrm{d}^{-1}$. Nevertheless, the habitat-wise differentiation in nitrification potential was distinct: the $\mathrm{PNR}_{\text {total }}$ of the vegetated sediments was on average $0.69 \pm 0.12 \mu \mathrm{mol} \mathrm{g}^{-1} \mathrm{~d}^{-1}$, which was about 3 times higher than that of the bare sediments $\left(0.23 \pm 0.04 \mu \mathrm{mol} \mathrm{g} \mathrm{g}^{-1}\right)(t$-test, $P$ $<0.05$; Fig. 1a). Inhibition assays indicated that the AOA oxidized $0.28 \pm 0.08 \mu \mathrm{mol} \mathrm{NH}_{4}{ }^{+} \mathrm{g}^{-1} \mathrm{~d}^{-1}$, accounting for $40.3 \%$ of nitrifying activity in the seagrass-colonized sites; the activity of AOA in the bare sediments was significantly lower $\left(0.10 \pm 0.02 \mu \mathrm{mol} \mathrm{g}^{-1} \mathrm{~d}^{-1} ; P=0.002\right)$, but contributed a similar percentage $(44.2 \%)$ to the total nitrification potential. As a result, the AOB showed a similar spatial pattern in activity by contributing the remaining $59.7 \%$ and $55.8 \%$ of nitrifying activities in the vegetated and unvegetated sediments, respectively, though the niche-wise difference was not significant ( $t$-test, $P=0.13$ ) (Fig. 1a).

\subsection{Abundance of amoA genes and correlations with environmental factors}

Overall, the abundance of both AOB and AOA varied greatly among all sites. The AOB was generally more abundant than AOA: the former had $1.08 \times 10^{6}$ to $9.95 \times 10^{6}$ copies of amoA genes in a gram of wet sediment across all sites investigated, which was about 20 times higher than the later $\left(0.6 \times 10^{5}\right.$ to $5.07 \times 10^{5}$ copies $\left.\mathrm{g}^{-1}\right)$. Nevertheless, neither AOB-amoA

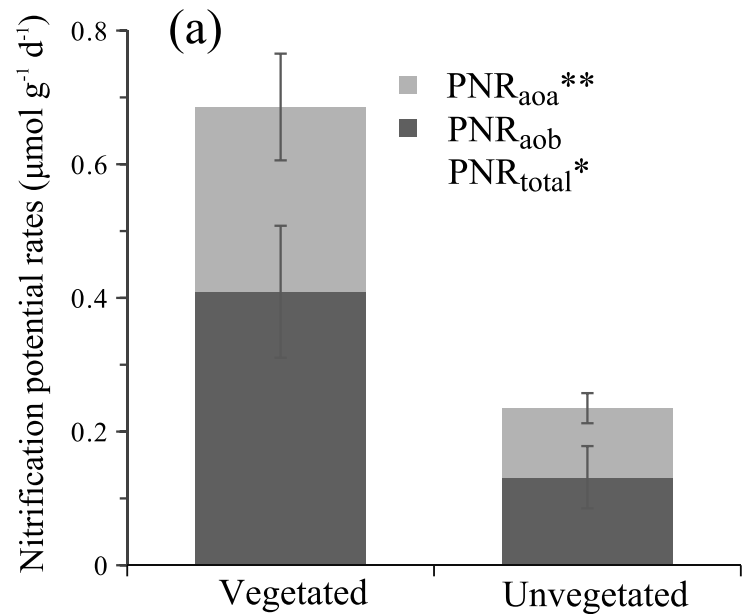

$\left[(3.72 \pm 1.16) \times 10^{6}\right.$ vs. $(5.98 \pm 1.64) \times 10^{6}$ copies $\left.\mathrm{g}^{-1}\right]$ nor AOA-amoA $\left[(2.21 \pm 0.76) \times 10^{5}\right.$ vs. $(3.24 \pm 0.58) \times 10^{5}$ copies $\mathrm{g}^{-1}$ ] was significantly different between the vegetated and unvegetated sediments ( $t$-test, $P>0.05$, Fig. 1b). The amoA gene ratio of $\mathrm{AOA}$ to $\mathrm{AOB}$ (AOA:AOB) ranged from 0.01 to 0.20 , and was not significantly different between these two habitats either $(P=0.94)$.

The AOB-amoA did not significantly correlate with any environmental factor $(P>0.05$; Table 1$)$. Nevertheless, the log-transformed AOA amoA copy number was positively correlated with both DIN $(r=0.75, P=0.013)$ and $\mathrm{PO}_{4}{ }^{3-}(r=$ $0.66, P=0.039)$, and negatively with the contents of many metals including $\mathrm{Pb}, \mathrm{Cr}, \mathrm{Mn}, \mathrm{Fe}, \mathrm{Co}, \mathrm{Ni}, \mathrm{Cu}, \mathrm{As}$, and $\mathrm{Cd}(P \leq$ $0.05)$. In addition, the $a m o A$ gene copy number ratio of AOA to AOB was negatively correlated with DO $(r=-0.86, P=$ $0.002)$ and positively with $\mathrm{PO}_{4}{ }^{3-}(r=0.70, P=0.024$, Table 1).

\subsection{Diversity and composition of $A O B$ and $A O A$ community}

A total of 89 distinct AOA-amoA T-RFs were identified via TRFLP analysis. The number of T-RFs ranged from 26 to 40 in a given sample, and on average $33 \pm 3 \mathrm{~T}$-RFs in vegetated sediments vs. $31 \pm 3$ in the unvegetated. Nevertheless, the OTU richness and alpha diversity indices of AOA were not significantly different between these two types of habitat $(t$ test, $P>0.05$, Fig. S1).

Altogether, 99 valid AOA amoA sequences were obtained from clone libraries and sequencing (Table S2). These sequences showed 77.5 to $100 \%$ similarity at the amino acid level. The coverages of the vegetated and unvegetated sediment libraries were $94.5 \%$ and $93.3 \%$, respectively, indicating that most major AOA genotypes have been recovered. At a $3 \%$ cutoff of amino acids, a total of 16 OTUs were identified, of which 6 OTUs were common between these two types of

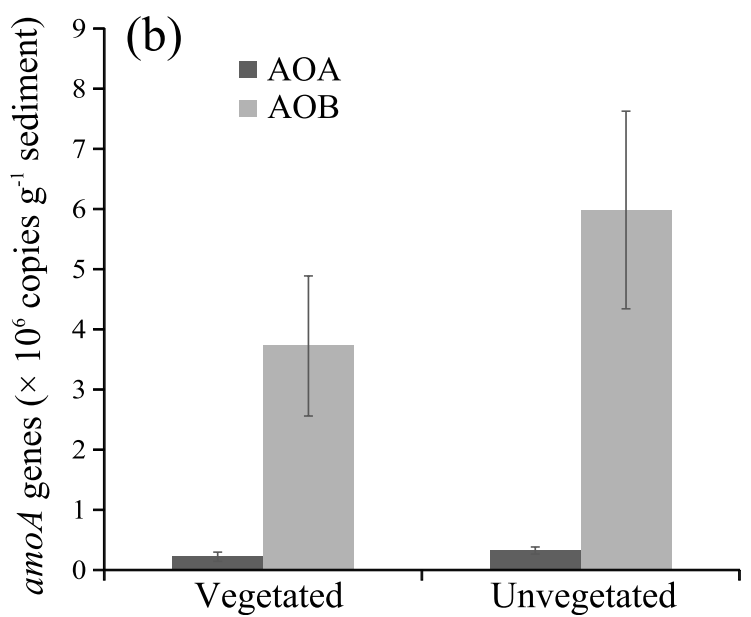

Fig. 1 Comparisons of the potential nitrification rates (a) and abundances of ammonia oxidizers (b) between the vegetated and unvegetated sediments. $t$ test, $* P<0.05 ; * * P<0.01$ 
Table 1 Pearson's correlation coefficients $(r)$ of the potential nitrification rates (PNR), relative contributions of AOA (AOA\%) and AOB (AOB\%), amoA gene abundances of $\mathrm{AOA}, \mathrm{AOB}$, and their ratios (AOA:AOB) with environmental variables in the seagrass ecosystem

\begin{tabular}{|c|c|c|c|c|c|c|c|c|}
\hline & $\mathrm{PNR}_{\text {total }}$ & $\mathrm{PNR}_{\text {aoa }}$ & $\mathrm{PNR}_{\mathrm{aob}}$ & $\mathrm{AOB} \%$ & $\mathrm{AOA} \%$ & $\lg (\mathrm{AOA}-a m o A)$ & $\lg (\mathrm{AOB}-a m o A)$ & AOA:AOB \\
\hline DO & 0.29 & 0.60 & -0.05 & -0.37 & 0.37 & -0.44 & 0.52 & $-0.86^{* *}$ \\
\hline Salinity & -0.04 & -0.11 & 0.02 & 0.29 & -0.29 & 0.39 & 0.18 & 0.00 \\
\hline Temperature & 0.27 & 0.32 & 0.13 & -0.22 & 0.22 & -0.52 & -0.33 & 0.05 \\
\hline Chl- $a$ & $0.78 * *$ & 0.55 & $0.63 *$ & 0.18 & -0.18 & -0.42 & -0.30 & 0.04 \\
\hline $\mathrm{pH}$ & 0.31 & 0.43 & 0.10 & -0.32 & 0.32 & -0.55 & -0.35 & 0.01 \\
\hline $\mathrm{NO}_{3}{ }^{-}$ & -0.10 & -0.07 & -0.08 & 0.27 & -0.27 & -0.18 & -0.59 & 0.49 \\
\hline $\mathrm{NO}_{2}^{-}$ & -0.49 & -0.46 & -0.32 & 0.31 & -0.31 & 0.11 & -0.50 & 0.50 \\
\hline $\mathrm{NH}_{4}^{+}$ & $-0.77 * *$ & -0.54 & -0.62 & -0.18 & 0.18 & 0.46 & 0.29 & -0.02 \\
\hline DIN & $-0.78^{* *}$ & $-0.64^{*}$ & -0.57 & -0.03 & 0.03 & $0.75^{*}$ & 0.22 & 0.39 \\
\hline $\mathrm{PO}_{4}^{3-}$ & -0.25 & -0.34 & -0.09 & 0.26 & -0.26 & $0.66^{*}$ & -0.20 & $0.69 *$ \\
\hline $\mathrm{DIN}: \mathrm{PO}_{4}{ }^{3-}$ & -0.50 & -0.24 & -0.49 & -0.35 & 0.35 & -0.11 & 0.62 & -0.58 \\
\hline Grain size & $-0.72 *$ & -0.53 & -0.56 & -0.07 & 0.07 & 0.21 & 0.04 & 0.08 \\
\hline TOC & 0.19 & 0.36 & -0.02 & -0.02 & 0.02 & -0.27 & -0.23 & -0.18 \\
\hline $\mathrm{TN}$ & 0.54 & 0.56 & 0.31 & 0.04 & -0.04 & -0.30 & -0.48 & 0.07 \\
\hline TOC:TN & -0.51 & -0.12 & -0.58 & -0.29 & 0.29 & -0.01 & 0.46 & -0.53 \\
\hline $\mathrm{Pb}$ & 0.46 & 0.42 & 0.30 & 0.10 & -0.10 & $-0.72 *$ & -0.17 & -0.26 \\
\hline $\mathrm{Cr}$ & 0.46 & 0.40 & 0.31 & 0.10 & -0.10 & $-0.71 *$ & -0.18 & -0.25 \\
\hline Mn & 0.28 & 0.25 & 0.19 & 0.13 & -0.13 & $-0.78^{* *}$ & -0.10 & -0.36 \\
\hline $\mathrm{Fe}$ & 0.44 & 0.40 & 0.29 & 0.09 & -0.09 & $-0.71^{*}$ & -0.14 & -0.28 \\
\hline Co & 0.47 & 0.43 & 0.31 & 0.09 & -0.09 & $-0.70^{*}$ & -0.15 & -0.27 \\
\hline $\mathrm{Ni}$ & 0.47 & 0.40 & 0.33 & 0.12 & -0.12 & $-0.71^{*}$ & -0.20 & -0.23 \\
\hline $\mathrm{Cu}$ & 0.52 & 0.49 & 0.33 & 0.09 & -0.09 & $-0.69^{*}$ & -0.19 & -0.23 \\
\hline $\mathrm{Zn}$ & 0.38 & 0.38 & 0.23 & 0.14 & -0.14 & -0.52 & -0.12 & -0.22 \\
\hline As & 0.38 & 0.23 & 0.33 & 0.33 & -0.33 & $-0.66^{*}$ & -0.36 & -0.04 \\
\hline $\mathrm{Cd}$ & 0.01 & 0.11 & -0.07 & -0.06 & 0.06 & $-0.73 *$ & 0.01 & -0.38 \\
\hline
\end{tabular}

$\mathrm{DIN}: \mathrm{PO}_{4}{ }^{3-}$ : to the ratio of DIN to $\mathrm{PO}_{4}{ }^{3-}$ concentration; TOC:TN: the ratio of TOC to TN. The amoA gene copy numbers were log-transformed to meet the homogeneity of variance requirements. Significant correlations were highlighted in bold. $* P<0.05 ; * * P<0.01 ; n=10$

sediment, 7 and 1 OTUs were unique to the vegetated and the unvegetated samples, respectively (Fig. 2).

The ML tree showed that all of the newly obtained AOA amoA sequences were grouped into two clusters: Crenarchaeota 1.1a (39 sequences) and Crenarchaeota $1.1 \mathrm{~b}$ (60 sequences) (Fig. 2). The cluster of Crenarchaeota 1.1b dominated the AOA community in the vegetated sediments, accounting for $87 \%$ of $a m o A$ sequences. In contrast, the phylotypes of Crenarchaeota 1.1 a occurred more frequently $(71 \%)$ in the unvegetated sediments, showing high sequence similarities (94.4-96.7\%) to those reported for a meadow of Z. marina in Japan (Ando et al. 2009). The most abundant AOA OTU was AOAFC19, which was more frequently presented in the unvegetated $(71.1 \%)$ than in the vegetated sediments $(11.1 \%)$. BLASTing against GenBank showed that this OTU was completely identical at amino acid level to the archaeal amoA gene of a tropical estuary of Arabian Sea (AXF48015) and to $C a$. Nitrosopelagicus brevis (WP_048104634), with a 96.7\% similarity to Nitrosopumilus maritimus (ADJ95198). The second abundant archaeal amoA OTU (AOAFC16) had a $98.1 \%$ similarity to $\mathrm{Ca}$. Nitrosocosmicus franklandus and $90 \%$ to Nitrososphaera viennensis (WP_075055648) at the translated protein level. AOAFC16 was more frequently detected in the vegetated (24.1\% vs. $4.4 \%$ ). Other OTUs of AOA (i.e., AOAC5, AOAC55, and AOAC19) sharing 94.3-95.0\% sequence identities with $C a$. Nitrosocosmicus sp. had higher proportions in the vegetated sediments as well (Fig. 2).

Regarding AOB, 362,939 high-quality AOB-amoA reads were obtained from Miseq sequencing. After rarefacting to 41,097 reads, 82 OTUs of bacterial amoA genes were identified, varying from 43 to 61 OTUs among samples. Similar to AOA, the diversity of AOB in the vegetated appeared to be higher than the unvegetated, but the statistical significance was never supported ( $t$-test, $P>0.05$, Fig. S1).

The AOB amoA sequences recovered in this study were affiliated to two genera, Nitrosospira and Nitrosomonas (Fig. 3a), with the latter dominating the AOB community (68.1 to $86.4 \%$ ) across all sites (Fig. 3a). There were six genotypes within Nitrosomonas, namely $N$. aestuarii, 


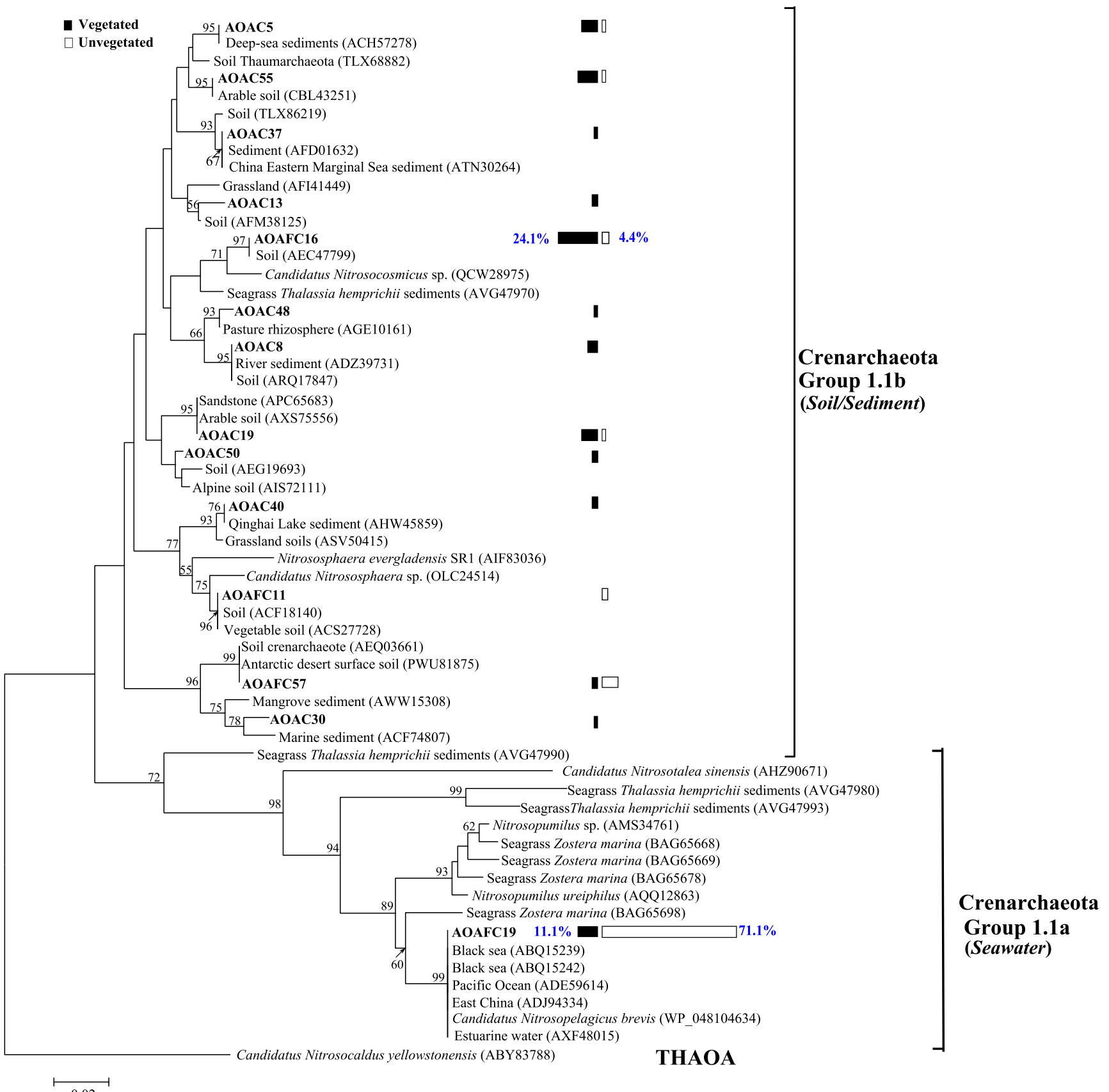

Fig. 2 A maximum likelihood tree showing the phylogenetic positions of archaeal ammonia oxidizers from the seagrass system based on amino acid sequences translated from the $a m o A$ gene sequences. The numbers of clones of each OTU in the libraries are indicated and shown as black (the vegetated) and white (the unvegetated) bars on the scale. Bootstrap values

N. cryotolerans, NL7, NS20, Nm143, and Nm47, of which $N$. cryotolerans was the most abundant, with a significantly higher proportion in the unvegetated sites $(79.2 \pm 4.1 \%)$ than in the vegetated $(54.3 \pm 9.3 \%, t$-test, $P=0.03$; Fig. $3 b)$. In contrast, another dominant genotype, NL7, was markedly enriched in the vegetated sediments $(11.1 \%$ vs. $0.06 \% ; P=$ 0.025). N. aestuarii and $\mathrm{Nm} 47$ were minor $(\leq 1 \%)$ and occurred only in the vegetated sediments. lower than $50 \%$ are not shown. The scale bar indicates 0.02 amino acid substitution per site. The AmoA protein sequence of $\mathrm{Ca}$. Nitrosocaldus yellowstonensis (THAOA) (Prosser and Nicol 2008) is used as the outgroup. The GenBank accession numbers are given in parentheses

The Nitrosospira was further classified into seven genotypes: 40KI, III2, NpAV, Nsp5, Nsp65, PJA1, and uncultured lineages, accounting for 7.3 to $31.1 \%$ of $\mathrm{AOB}$ in vegetated and unvegetated sites, respectively. The most dominant Nitrosospira genotype was $\mathrm{NpAV}$, which had a significantly higher relative abundance in the vegetated $(14.6 \%$ vs. $9.8 \%, P=$ 0.031). In addition, the genotypes Nsp65 and PJA1 were minor $(<0.5 \%)$ and exclusively detected in the unvegetated (Fig. 3). 


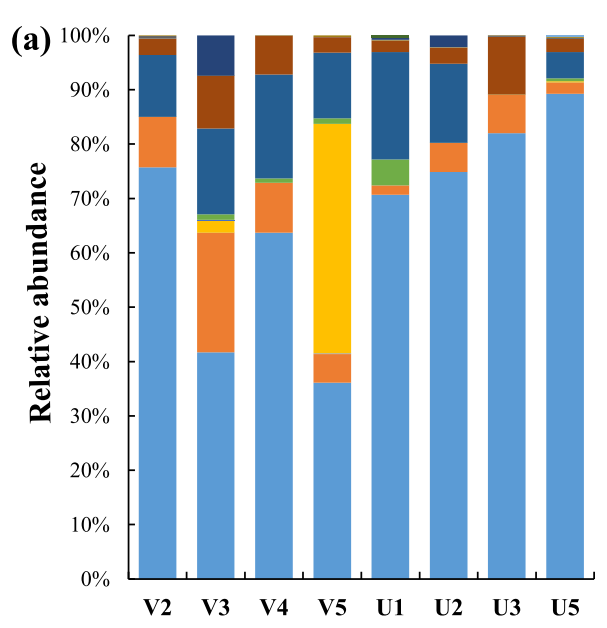

- Nitrosospira sp. PJA1

- Nitrosospira sp. Nsp65

- Nitrosospira sp. Nsp5

- Uncultured Nitrosospira sp.

- Nitrosospira sp. 40KI

- Nitrosospira sp. III2

- Nitrosospira sp. NpAV

- Nitrosomonas sp. Nm143

- Nitrosomonas aestuarii

$\because$ Nitrosomonas sp. NL7

- Nitrosomonas sp. $\mathrm{Nm} 47$

- Nitrosomonas sp. NS20

- Nitrosomonas cryotolerans

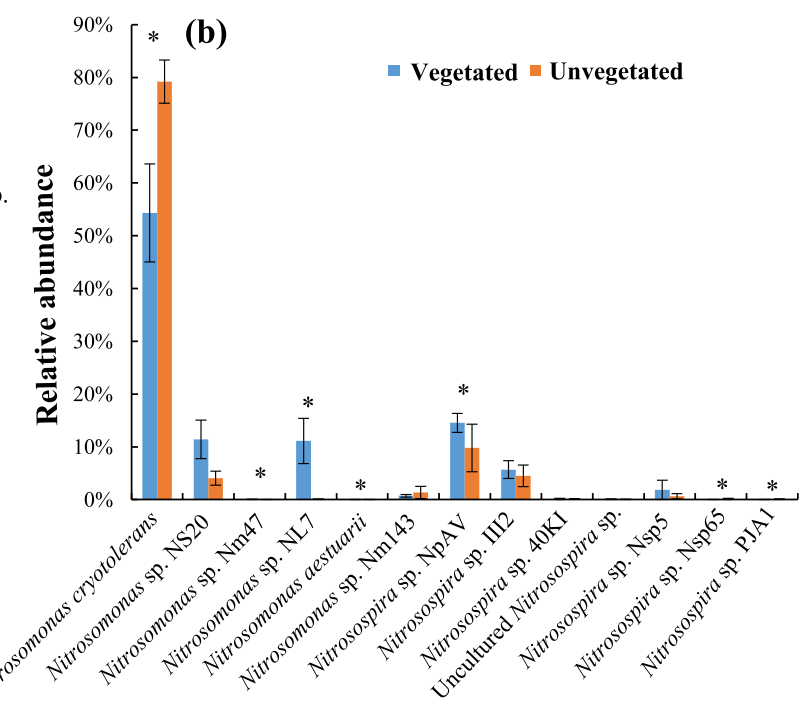

Fig. 3 a Distribution of the genotypes of AOB among sites. b Comparisons of the relative abundance of AOB genotypes between the vegetated and unvegetated sediments. The asterisks indicate significant differences between these two types of sediment $(P<0.05)$

\subsection{Variations in $A O A$ and $A O B$ community and driving environmental factors}

The nMDS ordination showed that both AOB and AOA communities in the vegetated sediments were clearly separated from those in the unvegetated (Fig. 4). Hypothesis testing using ANOSIM indicated that the difference in AOA community structure between these two niches was significant $(r=0.488$, $P=0.016$ ), but the difference in AOB community structure was not $(r=0.104, P=0.20)$. The RDA plot showed that the community structure of AOB co-varied significantly with DO in the overlying water $(P=0.005)$ and TOC:TN in the sediment $(P=0.02)$ (Fig. 5a), while the community structure of AOA was significantly driven by $\mathrm{NO}_{3}{ }^{-}$concentration in the pore water $(P=0.015)$ and $\mathrm{Fe}$ content in sediments $(P=0.01)$ (Fig. 5b).

The correlations between the proportions of major genotypes of AOB and environmental parameters showed that $N$. cryotolerans was positively correlated with TOC:TN $(r=$ $0.90, P<0.01), \mathrm{NH}_{4}^{+}(r=0.73, P<0.05)$, and negatively with Chl- $a(r=-0.71, P<0.05)$. NL7 had a negative correlation with TOC:TN $(r=-0.73, P<0.05)$. Both Nm143 and Nsp65 were promoted in the presence of higher $\mathrm{NO}_{3}{ }^{-}$and $\mathrm{NO}_{2}{ }^{-}$ concentrations $(r>0.80, P<0.05)$. The higher TN\% might have enhanced the proportions of the genotypes $N$. aestuarii, NS20, and Nsp5 $(r>0.78, P<0.05)$ (Table 2).

\subsection{Factors determining sediment PNR}

Across all samples, the $\mathrm{PNR}_{\text {total }}$ was significantly and positively correlated with Chl- $a(r=0.78, P \leq 0.01)$, and negatively with $\mathrm{NH}_{4}{ }^{+}$and DIN $(r=-0.77, P \leq 0.01)$ and GS $(r=$ $-0.78, P \leq 0.05$ ) (Table 1). Meanwhile, PNR aob was significantly and positively correlated with Chl- $a(r=0.63, P \leq$ $0.05)$, and PNR $_{\text {aoa }}$ was negatively correlated with DIN ( $r=$ $-0.64, P \leq 0.05)$. No any investigated environmental factors significantly determined the relative contributions of AOA and AOB (Table $1, P>0.05$ ). Neither AOA and AOB amoA gene abundance nor their alpha diversity estimators was significantly related to PNR in this study (Table S3, $P>$ $0.05)$.
Fig. 4 Nonmetric dimensional scaling (nMDS) for AOB (a) and AOA (b) communities based on MiSeq sequencing and T-RFLP profiling of amoA genes, respectively. Two-dimensional stress values $\leq 0.10$ indicate good ordinations
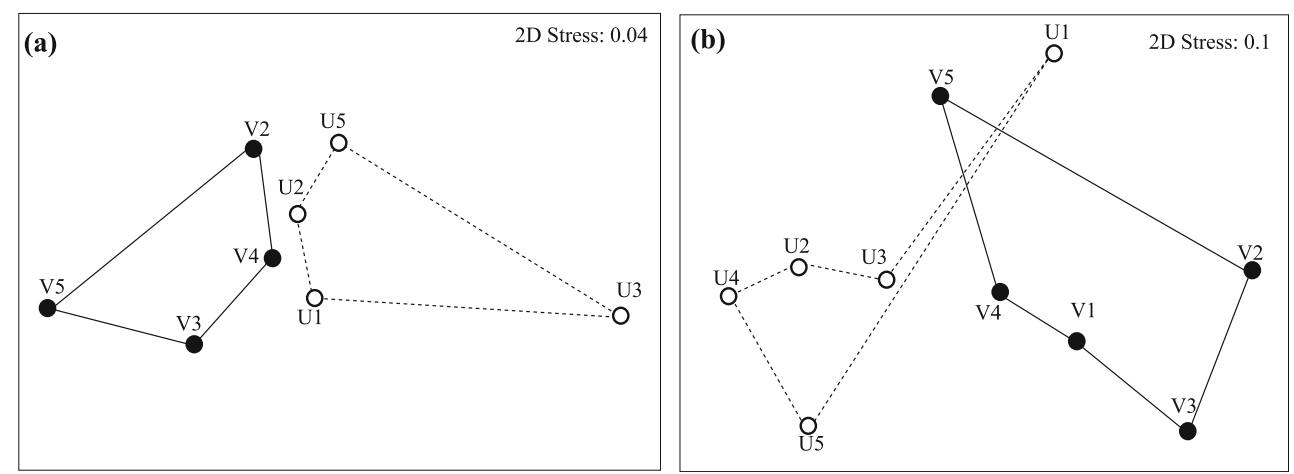
Fig. 5 RDA plots for $\mathrm{AOB}(\mathrm{a})$ and AOA (b), showing the major environmental parameters covarying with the community structures. Only the environmental factors of significant correlations $(P<0.05)$ are shown
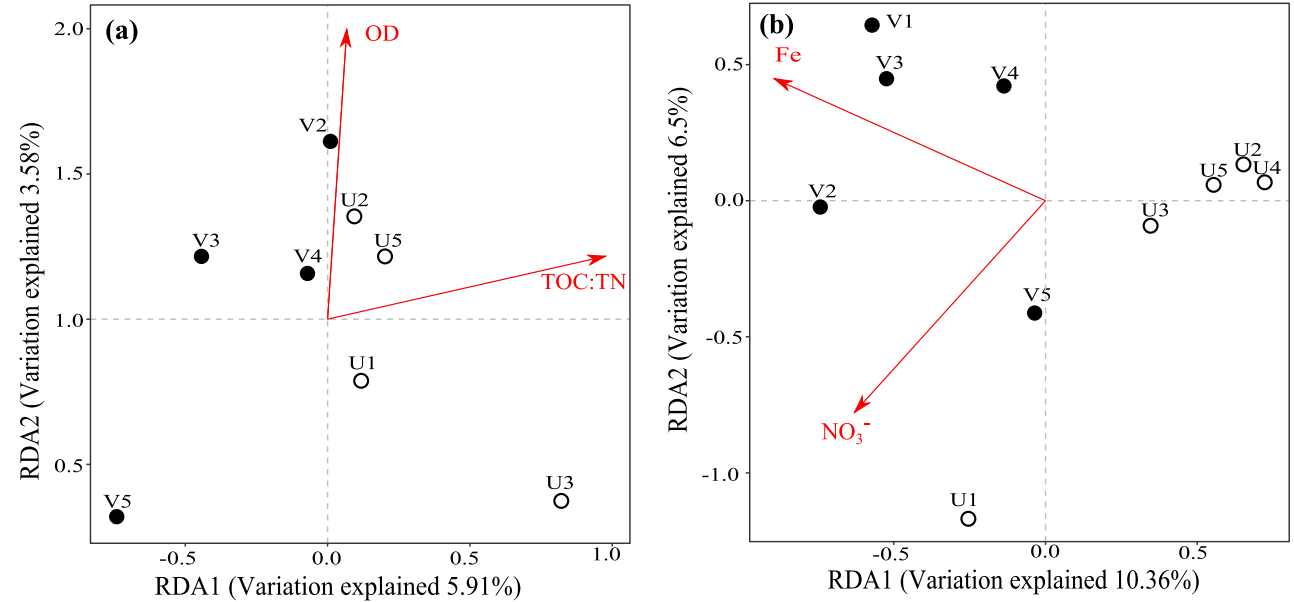

Table 2 Pearson's correlation coefficients $(r)$ between the relative abundance of AOB genotypes and environmental variables. Significant correlations are highlighted in bold $(P<0.05)$, and *significant at $P<0.05$, **significant at $P<0.01$

\begin{tabular}{|c|c|c|c|c|c|c|c|c|c|c|c|c|c|}
\hline \multicolumn{7}{|l|}{ Nitrosomonas } & \multicolumn{7}{|c|}{ Nitrosospira } \\
\hline & N. aestuarii & N. cryotolerans & NL7 & NS20 & $\mathrm{Nm} 143$ & $\mathrm{Nm} 47$ & $40 \mathrm{KI}$ & III2 & NpAV & Nsp5 & Nsp65 & PJA1 & Uncultured \\
\hline DO & 0.37 & 0.29 & -0.55 & 0.41 & -0.49 & -0.52 & 0.34 & -0.01 & -0.03 & 0.46 & -0.43 & 0.28 & -0.34 \\
\hline Salinity & -0.07 & 0.39 & -0.11 & -0.24 & -0.12 & -0.06 & 0.16 & -0.29 & -0.40 & -0.18 & -0.16 & $0.97 * *$ & 0.39 \\
\hline Temperature & 0.19 & -0.52 & 0.14 & 0.39 & 0.14 & 0.10 & -0.11 & 0.23 & 0.54 & 0.26 & 0.14 & $-0.99 * *$ & -0.33 \\
\hline Chl- $a$ & 0.38 & $-0.71 *$ & 0.40 & 0.62 & -0.20 & 0.40 & 0.06 & 0.19 & 0.37 & 0.25 & -0.37 & -0.39 & 0.17 \\
\hline $\mathrm{pH}$ & 0.25 & -0.45 & -0.003 & 0.47 & 0.06 & -0.04 & -0.01 & 0.28 & 0.53 & 0.33 & 0.08 & $-0.96 * *$ & -0.44 \\
\hline $\mathrm{NO}_{3}^{-}$ & -0.23 & -0.06 & 0.06 & -0.29 & $0.80 *$ & 0.08 & 0.11 & -0.3 & 0.36 & -0.31 & $0.84 * *$ & -0.35 & 0.17 \\
\hline $\mathrm{NO}_{2}^{-}$ & -0.18 & 0.31 & -0.18 & -0.52 & $0.83 *$ & -0.19 & -0.21 & -0.32 & 0.06 & -0.21 & $0.87 * *$ & 0.28 & 0.11 \\
\hline $\mathrm{NH}_{4}^{+}$ & -0.35 & 0.73 & -0.38 & -0.59 & 0.13 & -0.39 & -0.02 & -0.13 & -0.50 & -0.26 & 0.29 & 0.51 & -0.12 \\
\hline DIN & -0.44 & 0.30 & 0.32 & -0.68 & 0.03 & 0.32 & -0.14 & -0.31 & -0.58 & -0.39 & 0.09 & 0.51 & 0.47 \\
\hline $\mathrm{PO}_{4}{ }^{3-}$ & -0.18 & -0.05 & 0.56 & -0.41 & 0.02 & 0.58 & -0.15 & -0.28 & -0.47 & -0.29 & -0.08 & 0.68 & $0.77 *$ \\
\hline DIN:$: \mathrm{PO}_{4}{ }^{3-}$ & -0.27 & 0.35 & -0.29 & -0.27 & -0.13 & -0.31 & -0.05 & -0.18 & 0.05 & 0.001 & 0.06 & -0.26 & -0.38 \\
\hline GS & -0.34 & 0.46 & -0.34 & -0.54 & 0.54 & -0.36 & -0.16 & -0.22 & 0.03 & -0.19 & $0.71 *$ & -0.08 & -0.26 \\
\hline TOC (\%) & $0.72 *$ & 0.10 & -0.49 & 0.45 & 0.16 & -0.52 & -0.13 & 0.25 & -0.06 & 0.68 & 0.11 & 0.42 & -0.33 \\
\hline $\mathrm{TN}(\%)$ & $0.97 * *$ & -0.42 & -0.17 & $0.79 *$ & 0.10 & -0.23 & -0.34 & 0.41 & 0.20 & $0.93 * *$ & -0.05 & 0.06 & -0.30 \\
\hline TOC:TN & -0.24 & $0.90 * *$ & $-0.73 *$ & -0.33 & 0.01 & -0.69 & 0.48 & 0.01 & -0.52 & -0.22 & 0.23 & 0.42 & -0.36 \\
\hline $\mathrm{Pb}$ & 0.27 & -0.38 & 0.06 & 0.51 & -0.01 & 0.10 & 0.36 & 0.16 & 0.33 & 0.09 & -0.11 & -0.32 & 0.03 \\
\hline $\mathrm{Cr}$ & 0.29 & -0.43 & 0.10 & 0.54 & -0.04 & 0.13 & 0.32 & 0.23 & 0.30 & 0.10 & -0.15 & -0.34 & 0.03 \\
\hline $\mathrm{Mn}$ & -0.02 & -0.09 & -0.19 & 0.21 & 0.21 & -0.14 & 0.39 & -0.06 & 0.47 & -0.15 & 0.20 & -0.31 & -0.07 \\
\hline $\mathrm{Fe}$ & 0.20 & -0.31 & 0.02 & 0.46 & -0.03 & 0.06 & 0.41 & 0.16 & 0.29 & 0.02 & -0.11 & -0.31 & 0.02 \\
\hline $\mathrm{Co}$ & 0.24 & -0.37 & 0.08 & 0.50 & -0.07 & 0.12 & 0.39 & 0.15 & 0.30 & 0.06 & -0.16 & -0.30 & 0.06 \\
\hline $\mathrm{Ni}$ & 0.25 & -0.39 & 0.07 & 0.49 & 0.01 & 0.11 & 0.33 & 0.16 & 0.34 & 0.06 & -0.09 & -0.31 & 0.05 \\
\hline $\mathrm{Cu}$ & 0.32 & -0.42 & 0.10 & 0.56 & -0.03 & 0.13 & 0.37 & 0.19 & 0.28 & 0.14 & -0.13 & -0.34 & 0.04 \\
\hline $\mathrm{Zn}$ & 0.19 & -0.01 & -0.04 & 0.24 & -0.13 & 0.02 & 0.41 & -0.06 & -0.08 & -0.02 & -0.23 & 0.46 & 0.30 \\
\hline As & 0.06 & -0.30 & 0.13 & 0.15 & 0.34 & 0.17 & 0.17 & -0.18 & 0.44 & -0.14 & 0.22 & -0.05 & 0.30 \\
\hline $\mathrm{Cd}$ & 0.54 & -0.59 & 0.21 & 0.71 & -0.10 & 0.23 & 0.25 & 0.22 & 0.27 & 0.38 & -0.24 & -0.31 & 0.10 \\
\hline
\end{tabular}




\section{Discussion}

\subsection{The PNR and contributions of AOA and AOB between vegetated and unvegetated sediments}

In this study, $\mathrm{PNR}_{\text {total }}$ in surface sediments of the Z. marina meadow was estimated to be 0.15 to $1.0 \mu \mathrm{mol} \mathrm{g}^{-1}$ wet sediment $\mathrm{d}^{-1}$, which fell into the same range previously reported for seagrass meadows (Iizumi et al. 1980; Caffrey and Kemp 1990) and for estuarine and coastal marine sediments (Berounsky and Nixon 1985; Zheng et al. 2014). By comparing the vegetated with unvegetated sediments, we showed that the colonization of $Z$. marina significantly enhanced the microbial driving $\mathrm{PNR}_{\text {total }}$ in the seagrass ecosystem, which supports Caffrey and Kemp (1990) and Iizumi et al. (1980), who studied the benthic nitrification in Z. marina meadows in America and found similar results. Nevertheless, several other studies (i.e., Rysgaard et al. 1996; Ottosen et al. 1999) demonstrated that the nitrification rate was lower in seagrass vegetated than in bulk sediments, which could be primarily due to limited production of $\mathrm{NH}_{4}{ }^{+}$via remineralization of organic matter, competition for $\mathrm{NH}_{4}{ }^{+}$by seagrasses, lower oxygen penetration into the sediment, and inhibition by sulfide, the product of anaerobic sulfate reduction (Caffrey and Kemp 1990; Rysgaard et al. 1996; Ottosen et al. 1999). These situations seemed to be not prevalent at the time we performed sampling: the seagrass was actively growing in the late spring, in which the remineralized nutrients (e.g. $\mathrm{NH}_{4}^{+}$) putatively still sustained at high levels (Table S1), and photosynthesis of the seagrass was becoming increasingly active, resulting in more oxygen release to the root zone. Despite that the $\mathrm{NH}_{4}{ }^{+}$ concentration was lower in the vegetated sediments than the bulk, these levels of $\mathrm{NH}_{4}{ }^{+}(386-448 \mu \mathrm{M})$ were not low enough to limit ammonia oxidization, since the saturate $\mathrm{NH}_{4}{ }^{+}$concentrations of in situ ammonia oxidations were generally $<100 \mu \mathrm{M}$ (Martens-Habbena et al. 2009). In contrast, the availability of oxygen is likely to be the key for nitrification activity in the sediments, for which our observation of the strong positive correlation between the overlying water Chl- $a$ concentration (and hence oxygen production and penetration into the sediments) and PNR total supports (Table 1).

This study is the first assessment of relative contributions of $\mathrm{AOA}$ and $\mathrm{AOB}$ to benthic ammonia oxidation in the seagrass system. Our results showed that AOB contributed higher (approximately 58\%) than AOA (Fig. 1), which was consistent with the conclusion in the seagrass $T$. hemprichii patches of coral reef ecosystems (Ling et al. 2018) based on the comparison of amoA gene abundance between AOA and AOB. AOB have been previously reported to contribute substantially in nitrification activity in eutrophic coastal or lake sediments, such as Rushan Bay (He et al. 2018) and Danjiangkou reservoir (Dang et al. 2018), while AOA normally predominated in nitrification in seawaters (Berg et al.
2015). Therefore, we speculated that organic matter and ammonia accumulation lead to the dominant role of $\mathrm{AOB}$ in nitrification (He et al. 2018; Dang et al. 2018), for which the strong positive correlation between $\mathrm{PNR}_{\mathrm{aob}}$ and the Chl- $a$ concentration (also representing labile organic matter) in the overlying water supported (Table 1). Benefiting from seagrasses slowing down the water flow, many planktonic and epiphytic microalgae inhabit in the seagrass patches. These labile organic loading supplies continuous $\mathrm{NH}_{4}{ }^{+}$for AOB and alleviates $\mathrm{NH}_{4}{ }^{+}$competition by seagrass. However, PNR $_{\text {aoa }}$ had a negative correlation with the DIN concentration. A recent study has provided a solid evidence for the higher activity of AOA in lower $\mathrm{NH}_{4}{ }^{+}$concentration ( $\leq$ $7.14 \mu \mathrm{M})$ and AOB in higher $\mathrm{NH}_{4}{ }^{+}$concentration $(\geq 142.86$ $\mu \mathrm{M})$ by laboratory cultivation of coastal sediments (Zhang et al. 2015b). In addition, physiological inhibition by excessive $\mathrm{NH}_{4}{ }^{+}$on AOA has also been reported (Hatzenpichler et al. 2008). Zhang et al. (2015b) addressed that AOA activity would be inhibited when the environmental $\mathrm{NH}_{4}{ }^{+}$exceeded $333 \mu \mathrm{M}$. The $\mathrm{NH}_{4}{ }^{+}$concentrations in this study ranged from 386.4 to $1093.6 \mu \mathrm{M}$ with much higher values in the bare region (Table S1), and thus AOA activity may be inhibited by high DIN in the bare region. In addition, the organic carbon secreting from seagrass roots could stimulate AOA, since many members of which possess versatile mixotrophic ability (utilizing both $\mathrm{CO}_{2}$ and organic carbon) (Jia and Conrad 2009; Wessén et al. 2010; Prosser and Nicol 2012; Chan et al. 2013).

\subsection{Abundances of $A O B$ and $A O A$ in the seagrass system}

The qPCR quantification of the functional genes indicated that AOB generally outnumbered AOA in the sedimentary system of $Z$. marina, which is in line with the study of the tropical seagrass species $T$. hemprichii growing in oligotrophic sediments of the coral reef system (Ling et al. 2018). In contrast, the abundance of AOA and $\mathrm{AOB}$ were found to be almost equal in $\mathrm{N}$-limited, sandy sediments of $Z$. marina in Japan (Ando et al. 2009), suggesting that the quantity of AOA and AOB in seagrass sediments may be subject to biological and chemical properties of the seagrass species, geographic location, and local environmental conditions. We found that there were high variance in $\mathrm{AOA}$ and $\mathrm{AOB}$ abundances and no significant difference between the vegetated and unvegetated sediments, indicating there was high heterogeneity within each type of these two habitats. The environmental factors affecting the abundance of AOA seemed to be DIN and $\mathrm{PO}_{4}{ }^{3-}$ in pore water (Table 1), indicating that the lower $\mathrm{AOA}$ abundance in the vegetated sites might be due to nutrient (especially P) competition by seagrass, whose roots must have taken up massive pore water $\mathrm{N}$ and $\mathrm{P}$ during growing seasons. Furthermore, the lower concentration of DIN might also be attribute to higher nitrification (as we observed in this study) 
and tightly coupled denitrification (e.g., production of $\mathrm{N}_{2}$ and/ or $\mathrm{N}_{2} \mathrm{O}$ ) (Zarnoch et al. 2017; Aoki et al. 2020), which also lowered the DIN in the vegetated sediments. There were also significant and negative correlations between AOA abundance and sediment metals (Table 1), suggesting that higher metal levels in vegetated sediments maybe toxic to AOA (Liu et al. 2014). In line with our results, significantly higher AOA and AOB abundances in the bulk soils than in the Phragmites communis rhizosphere soils were also found in the riparian zone (Wang et al. 2019).

\subsection{Seagrass colonization selected specific lineages of ammonia oxidizers}

There was obvious discrepancy in AOA and AOB community structures between the two types of sediment. Nitrosomonas dominated in AOB community among all samples (Fig. 3a). This finding is similar to others, e.g., the Colne Estuary ( $\mathrm{Li}$ et al. 2015), the Hangzhou Bay (Zhang et al. 2015b), the hypernutrified Bahía del Tóbari Estuary (Beman and Francis 2007), and the polluted mangrove (Cao et al. 2011). Higher $\mathrm{NH}_{4}{ }^{+}$supported high proportions of Nitrosomonas in these environments (see Table 3 for the half saturation constants for ammonia of various $\mathrm{AOB}$ isolates). It was interesting that in the N-limited $\left(\mathrm{NH}_{4}^{+} \leq 660 \mu \mathrm{mol} \mathrm{g}{ }^{-1}\right)$ Z. marina sands of Tanoura Bay, Nitrosospira dominated in the in situ AOB community, but after the enrichment incubation with $4 \mathrm{mM}$ $\mathrm{NH}_{4}{ }^{+}$, the dominant AOB population shift to Nitrosomonas (Ando et al. 2009). Furthermore, from the view of habitat selection, Nitrosomonas mainly occurs in marine sediments (Zhang et al. 2015b; Ling et al. 2018), while Nitrosospira was more adaptable in soils and freshwater sediments (Jia and Conrad 2009; Wang et al. 2019) (Table 3).

The most abundant AOB genotype Nitrosomonas cryotolerans sharply increased from the vegetated samples to the bare samples (Fig. 3b). Based on the correlations of Table 2, N. cryotolerans throve in higher $\mathrm{NH}_{4}{ }^{+}$and TOC:TN habitats. $N$. cryotolerans has been generally found in bioreactors, aquaculture biofilm, wastewater treatment plants, and estuaries (Purkhold et al. 2003; Tal et al. 2003; Pal et al. 2012), suggesting its adaptation to high $\mathrm{N}$, and the pure culture evidence has confirmed its $\mathrm{NH}_{4}{ }^{+}$tolerance up to $400 \mathrm{mM}$ (Jones et al. 1988). It was because of the low $\mathrm{N}$ affinity (i.e., high $K_{m}$ ), $N$. cryotolerans is a poor competitor for $\mathrm{NH}_{4}{ }^{+}$with seagrass in the vegetated sites. In addition, more labile organic matter (lower TOC:TN) in vegetated sediments stimulate heterotrophic bacteria, another strong competitor for ammonia with $N$. cryotolerans, which could suppress $N$. cryotolerans as well. In contrast to $N$. cryotolerans, another abundant Nitrosomonas genotype NL7 (affiliated to Nitrosomonas oligotropha) presented higher proportions in the vegetated samples (Fig. 3b). It was probably due to high affinity for ammonia and low affinity for oxygen of NL7 as demonstrated by Park and Noguera (2007), the availability of which was supported by low $\mathrm{N}$ and high oxygen of the vegetated habitats. Compared to Nitrosomonas, Nitrosospira generally have higher ammonia affinities (Table 3 ), which could help the abundant Nitrosospira genotype, $\mathrm{NpAV}$, to compete $\mathrm{NH}_{4}{ }^{+}$with seagrasses in vegetated sediments (Fig. 3b). Furthermore, sediment TOC:TN played a key role in regulating the whole AOB community structure (Fig. 5a). This is possible because some AOB populations can assimilate organic $\mathrm{N}$ compound, but some others will be inhibited by the nitrogen-compound even at very low concentration (Jensen 1950; Krümmel and Harms 1982; Dai et al. 2018).

Compared with AOB community, AOA community were more sensitive to the seagrass colonization. Two distinct AOA groups Crenarchaeota $1.1 \mathrm{~b}$ and Crenarchaeota 1.1 a dominated in the AOA communities of vegetated and unvegetated sediments, respectively (Fig. 2). The result differed sharply from the discovery of Ando et al. (2009), in which all of the AOA sequences from $Z$. marina vegetated sands fell into the Crenarchaeota 1.1a cluster. This is possibly because that different trophic states of the two $Z$. marina meadows selected different AOA communities. Crenarchaeota $1.1 \mathrm{a}$ and $1.1 \mathrm{~b}$ have been reported with some notable differences in their growth requirements and ammonia affinities based on the cultivated isolates (Könneke et al. 2005; Tourna et al. 2011; Bayer et al. 2016; Lehtovirta-Morley et al. 2016). The Crenarchaeota 1.1a group (representative species, Nitrosopumilus maritimus) can grow autotrophically with high affinity for ammonia (Table 3). However, Crenarchaeota 1.1b (Nitrososphaera viennensis) can grow mixotrophically, for example, require supplementation with pyruvate to achieve continuous growth and reasonably high biomass (Tourna et al. 2011; Stieglmeier et al. 2014), and is able to tolerate higher $\mathrm{NH}_{4}{ }^{+}$ concentrations (Table 3). Accordingly, the seagrasscolonized sediments with labile organic loading and continuous $\mathrm{NH}_{4}{ }^{+}$mineralization could delight Crenarchaeota $1.1 \mathrm{~b}$, while the barren bare sediments favorite Crenarchaeota 1.1a. In addition to niche selection, ecological adaption could be an important reason. According to phylogenetic analyses, most marine sequences were placed into Crenarchaeota 1.1a group, while most terrestrial sequences were clustered into Crenarchaeota $1.1 \mathrm{~b}$ (Ochsenreiter et al. 2003; Francis et al. 2005). The Crenarchaeota $1.1 \mathrm{~b}$ group was also frequently detected in the coastal sediments deriving from runoff input ( $\mathrm{He}$ et al. 2018; Dang et al. 2018). In our seagrass meadow, Crenarchaeota $1.1 \mathrm{~b}$ could adapt better to the vegetated sediments and flourish to become the dominant group.

RDA analysis results indicated the significant effects of $\mathrm{Fe}$ on the distribution of the whole AOA community, with AOA 
Table 3 The activity kinetics and preferred habitats of ammonia-oxidizing bacteria isolates

\begin{tabular}{|c|c|c|c|c|}
\hline Isolate & $\begin{array}{l}K_{m} \\
\left(\mathrm{NH}_{3}+\mathrm{NH}_{4}^{+}\right) \\
(\mu \mathrm{M})\end{array}$ & $\begin{array}{l}K_{m} \mathrm{O}_{2} \\
(\mu \mathrm{M})\end{array}$ & Habitat & Reference \\
\hline Nitrosomonas europaea & $29-3560$ & $6.9-17.4$ & $\begin{array}{l}\text { Sewage treatment plants; } \\
\text { eutrophic and saline water }\end{array}$ & $\begin{array}{l}\text { Suzuki et al. 1974; Laanbroek and Gerards 1993; } \\
\quad \text { Laanbroek et al. } 1994\end{array}$ \\
\hline Nitrosomonas mobilis & 30.7 & 21.74 & Sewage treatment plants & Thandar et al. 2016 \\
\hline Nitrosomonas communis & $18-19$ & $3.6-12.4$ & Soil; eutrophic freshwater & $\begin{array}{l}\text { Koops et al. 1991; Koops and Pommerening-Röser } \\
\text { 2001; Bouskill et al. } 2012\end{array}$ \\
\hline Nitrosomonas nitrosa & $19-46$ & $4.2-14$ & Eutrophic freshwater & Koops and Pommerening-Röser 2001 \\
\hline Nitrosomonas marina & $50-52$ & $11-23$ & Marine & $\begin{array}{l}\text { Koops and Pommerening-Röser 2001; } \\
\text { Bouskill et al. } 2012\end{array}$ \\
\hline Nitrosomonas aestuarii & $50-52$ & ND & Marine & Koops and Pommerening-Röser 2001 \\
\hline Nitrosomonas cryotolerans & $42-59$ & $11-23$ & Marine & $\begin{array}{l}\text { Jones et al. 1988; Koops and Pommerening-Röser } \\
\text { 2001; Bouskill et al. } 2012\end{array}$ \\
\hline Nitrosomonas oligotropha & $1.9-4.2$ & $1.4-4.7$ & Soil; oligotrophic water & Koops and Pommerening-Röser 2001 \\
\hline Nitrosospira spp. & $6-11$ & $0.7-1.2$ & Soil; freshwater & $\begin{array}{l}\text { Jiang and Bakken 1999; Martikainen and } \\
\quad \text { Nurmiaho-Lassila 2011; Bouskill et al. } 2012\end{array}$ \\
\hline $\begin{array}{l}\text { Nitrosopumilus maritimus } \\
\quad \text { (Crenarchaea 1.1a) }\end{array}$ & $0.13-0.61$ & $1.17-3.91$ & Marine & Martens-Habbena et al. 2009; Park et al. 2010 \\
\hline $\begin{array}{l}\text { Nitrososphaera viennensis } \\
\quad \text { (Crenarchaea } 1.1 \mathrm{~b})\end{array}$ & $2600^{\#}$ & ND & Soil & Stieglmeier et al. 2014; Tourna et al. 2011 \\
\hline
\end{tabular}

$K_{m}\left(\mathrm{NH}_{3}+\mathrm{NH}_{4}{ }^{+}\right)$: the half saturation constant for $\mathrm{NH}_{3}+\mathrm{NH}_{4}{ }^{+} ; K_{m} \mathrm{O}_{2}$ : the half saturation constant for $\mathrm{O}_{2} .{ }^{\#}$ The optimal growth concentration; $N D$, no data

in vegetated sediments (soil/sediment group) preferring high Fe condition (Fig. 5b). Stieglmeier et al. (2014) found that the genome of soil AOA $N$. viennensis carries genes for the ferritin/Dps domain proteins and the cells often contained electron-dense particles, proposing that the electron-dense particles and proteins may have a role in iron storage and protecting cells against oxidative stress by binding iron.

\section{Conclusions and outlook}

In the fertile temperate $Z$. marina seagrass meadow, the benthic PNR was significantly promoted by seagrass colonization, and AOB contributed more than AOA. The organic loading and DIN level in sediments controlled the PNR. Seagrass colonization selectively enriched specific lineages of AOB and AOA: Nitrosomonas dominated in the AOB community, of which NL7 presented significantly higher proportion in the vegetated region, while $N$. cryotolerans was more adaptable in the bare; two distinct AOA groups Crenarchaeota $1.1 \mathrm{~b}$ and Crenarchaeota $1.1 \mathrm{a}$ were prevalent in the vegetated and unvegetated sediments, respectively. Available $\mathrm{NH}_{4}{ }^{+}$, TOC:TN, and metal levels determined the distributions of $\mathrm{AOA}$ and $\mathrm{AOB}$ community in the seagrass system. It is worth mentioning that amoA gene abundance cannot well predict the potential nitrification activities and relative contributions of $\mathrm{AOA}$ and $\mathrm{AOB}$ in the seagrass ecosystem, since significant difference was observed for $\mathrm{PNR}_{\text {total }}$ and $\mathrm{PNR}_{\mathrm{aoa}}$, but not for abundance of either the two types of ammonia-oxidizing organisms. In the further studies, transcriptional data should be included for a better understanding the nitrification process and related microbial driving mechanisms in seagrass meadow ecosystems. Also, seasonal variations should be considered since the growing state of seagrass affects sediment $\mathrm{NH}_{4}{ }^{+}$, TOC:TN, and DO, and further affects benthic nitrification.

Supplementary Information The online version contains supplementary material available at https://doi.org/10.1007/s11368-021-02951-w.

Funding This work was jointly supported by the Natural Science Foundation of China (No. 41676154, 41976115), the grant from the Strategic Priority Research Program of the Chinese Academy of Sciences (No. XDA23050303), the Key Research and Development project of Yantai (2017ZH095), the Key Research Program of Frontier Sciences of CAS (No. QYZDB-SSW-DQC013, QYZDB-SSWDQC041), the China Postdoctoral Science Foundation (No. 2019M653151), and the Fundamental Research Funds for the Central Universities (No. 19lgpy93, 181gzd07).

\section{Declarations}

Human and animal rights and informed consent The article does not contain any studies with human participants or animals.

Conflict of interest The authors declare no competing interests. 


\section{References}

Ando Y, Nakagawa T, Takahashi R, Yoshihara K, Tokuyama T (2009) Seasonal changes in abundance of ammonia-oxidizing archaea and ammonia-oxidizing bacteria and their nitrification in sand of an eelgrass zone. Microbes Environ 24:21-27. https://doi.org/10.1264/ jsme2.ME08536

Aoki LR, McGlathery KJ, Oreska MPJ (2020) Seagrass restoration reestablishes the coastal nitrogen filter through enhanced burial. Limnol Oceanogr 65:1-12. https://doi.org/10.1002/lno.11241

Barbier EB, Hacker SD, Kennedy C, Koch EW, Stier AC, Silliman BR (2011) The value of estuarine and coastal ecosystem services. Ecol Monogr 81:169-193. https://doi.org/10.1890/10-1510.1

Bayer B, Vojvoda J, Offre P, Alves RJE, Elisabeth NH, Garcia JAL, Volland JM, Srivastava A, Schleper C, Herndl GJ (2016) Physiological and genomic characterization of two novel marine thaumarchaeal strains indicates niche differentiation. ISME J 10: 1051-1063. https://doi.org/10.1038/ismej.2015.200

Beman M, Francis C (2007) Diversity of ammonia-oxidizing archaea and bacteria in the sediments of a hypernutrified subtropical estuary: Bahía del Tóbari, Mexico. Appl Environ Microbiol 72:7767-7777. https://doi.org/10.1128/AEM.00946-06

Berg C, Vandieken V, Thamdrup B, Juergens K (2015) Significance of archaeal nitrification in hypoxic waters of the Baltic Sea. ISME J 9: 1319-1332. https://doi.org/10.1038/ismej.2014.218

Berounsky VM, Nixon SW (1985) Eutrophication and the rate of net nitrification in a coastal marine ecosystem. Estuar Coast Shelf S 20:773-781. https://doi.org/10.1016/0272-7714(85)90032-0

Bouskill NJ, Tang J, Riley WJ, Brodie EL (2012) Trait-based representation of biological nitrification: model development, testing, and predicted community composition. Front Microbiol 3:364. https:// doi.org/10.3389/fmicb.2012.00364

Caffrey J, Kemp WM (1990) Nitrogen cycling in sediments with estuarine populations of Potamogeton perfoliatus and Zostera marina. Mar Ecol Prog Ser 66:147-160. https://doi.org/10.3354/ meps066147

Cao HL, Li M, Hong YG, Gu JD (2011) Diversity and abundance of ammonia-oxidizing archaea and bacteria in polluted mangrove sediment. Syst Appl Microbiol 34:513-523. https://doi.org/10.1016/j. syapm.2010.11.023

Chan YK, McCormick WA, Ma BL (2013) Effects of inorganic fertilizer and manure on soil archaeal abundance at two experimental farms during three consecutive rotation-cropping seasons. Appl Soil Ecol 68:26-35. https://doi.org/10.1016/j.apsoil.2013.03.004

Cole JR, Wang Q, Fish JA, Chai BL, McGarrell DM, Sun YN, Brown CT, Porras-Alfaro A, Kuske CR, Tiedje JM (2014) Ribosomal Database Project: data and tools for high throughput rRNA analysis. Nucleic Acids Res 42:D633-D642. https://doi.org/10. 1093/nar/gkt1244

Dai LL, Liu CG, Yu LQ, Song CF, Peng L, Li XL, Tao L, Li G (2018) Organic matter regulates ammonia-oxidizing bacterial and archaeal communities in the surface sediments of Ctenopharyngodon idellus Aquaculture Ponds. Front Microbiol 9:2290. https://doi.org/10. 3389/fmicb.2018.02290

Dang CY, Liu W, Lin YX, Zheng MS, Jiang H, Chen Q, Ni JR (2018) Dominant role of ammonia-oxidizing bacteria in nitrification due to ammonia accumulation in sediments of Danjiangkou reservoir, China. Appl Microbiol Biotechnol 102:3399-3410. https://doi.org/ 10.1007/s00253-018-8865-0

Darriba D, Taboada GL, Doallo R, Posada D (2011) ProtTest 3: fast selection of best-fit models of protein evolution. Bioinformatics 27:1164-1165. https://doi.org/10.1093/bioinformatics/btr088

Fish JA, Chai BL, Wang Q, Sun YN, Brown CT, Tiedje JM, James RC (2013) FunGene: the functional gene pipeline and repository. Front Microbiol 4:291. https://doi.org/10.3389/fmicb.2013.00291
Francis CA, Roberts KJ, Beman JM, Santoro AE, Oakley BB (2005) Ubiquity and diversity of ammonia-oxidizing archaea in water columns and sediments of the ocean. Proc Natl Acad Sci U S A 102: 14683-14688. https://doi.org/10.1073/pnas.0506625102

Hall TA (1999) BioEdit: a user friendly biological sequence alignment editor and analysis program for windows 95/98/NT. Nucleic Acids Symp Ser 41:95-98

Hatzenpichler R, Lebedeva EV, Spieck E, Stoecker K, Richter A, Daims H, Wagner M (2008) A moderately thermophilic ammoniaoxidizing crenarchaeote from a hot spring. Proc Natl Acad Sci U S A 105:2134-2139. https://doi.org/10.1073/pnas.0708857105

Hauxwell J, Cebrian J, Valiela I (2003) Eelgrass Zostera marina loss in temperate estuaries: relationship to land-derived nitrogen loads and effect of light limitation imposed by algae. Mar Ecol Prog Ser 247: 59-73. https://doi.org/10.3354/meps247059

He H, Zhen Y, Mi TZ, Fu LL, Yu ZG (2018) Ammonia-oxidizing archaea and bacteria differentially contribute to ammonia oxidation in sediments from adjacent waters of Rushan Bay, China. Front Microbiol 9:116. https://doi.org/10.3389/fmicb.2018.00116

Iizumi H, Hattori A, McRoy CP (1980) Nitrate and nitrite in interstitial waters of eelgrass beds in relation to the rhizosphere. J Exp Mar Biol Ecol 47:191-201. https://doi.org/10.1016/0022-0981(80)90112-4

Jensen HL (1950) Effect of organic compounds on Nitrosomonas. Nature 165:974-974

Jia Z, Conrad R (2009) Bacteria rather than archaea dominate microbial ammonia oxidation in an agricultural soil. Environ Microbiol 11: 1658-1671. https://doi.org/10.1111/j.1462-2920.2009.01891.x

Jiang QQ, Bakken LR (1999) Comparison of Nitrosospira strains isolated from terrestrial environments. FEMS Microbiol Ecol 30:171-186. https://doi.org/10.1111/j.1574-6941.1999.tb00646.x

Jones RD, Morlta RY, Koops HP, Watson S (1988) A new marine oxidizing bacterium, Nitrosornonas cryotolerans sp. nov. Can J Microbiol 34:1122-1128. https://doi.org/10.1139/m88-198

Könneke M, Bernhard AE, de la Torre JR, Walker CB, Waterbury JB, Stahl DA (2005) Isolation of an autotrophic ammonia-oxidizing marine archaeon. Nature 437:543-546. https://doi.org/10.1038/ nature 03911

Koops HP, Pommerening-Röser A (2001) Distribution and ecophysiology of the nitrifying bacteria emphasizing cultured species. FEMS Microbiol Ecol 37:1-9. https://doi.org/10.1016/S0168-6496(01) 00137-4

Koops HP, Böttcher B, Möller UC, Pommerening-Röser A, Stehr G (1991) Classification of eight new species of ammonia-oxidizing bacteria: Nitrosomonas communis sp. nov., Nitrosomonas ureae sp. nov., Nitrosomonas aestuarii sp. nov., Nitrosomonas marina sp. nov., Nitrosomonas nitrosa sp. nov., Nitrosomonas eutropha sp. nov., Nitrosomonas oligotropha sp. nov. and Nitrosomonas halophila sp. nov. J Gen Microbiol 137:1689-1699

Krümmel A, Harms H (1982) Effect of organic matter on growth and cell yield of ammonia-oxidizing bacteria. Arch Microbiol 133:50-54

Laanbroek HJ, Gerards S (1993) Competition for limiting amounts of oxygen between Nitrosomonas europaea and Nitrobacter winogradskyi grown in mixed continuous cultures. Arch Microbiol 159:453-459

Laanbroek HJ, Bodelier PLE, Gerards S (1994) Oxygen consumption kinetics of Nitrosomonas europaea and Nitrobacter hamburgensis grown in mixed continuous cultures at different oxygen concentrations. Arch Microbiol 161:156-162

Lehtovirta-Morley LE, Ross J, Hink L, Weber EB, Gubry-Rangin C, Thion C, Prosser J, Nicol G (2016) Isolation of "Candidatus Nitrosocosmicus franklandus", a novel ureolytic soil archaeal ammonia oxidiser with tolerance to high ammonia concentration. FEMS Microbiol Ecol 92:fiw057. https://doi.org/10.1093/ femsec/fiw057

Li M, Cao HL, Hong YG, Gu JD (2011) Spatial distribution and abundances of ammonia-oxidizing archaea (AOA) and ammonia- 
oxidizing bacteria (AOB) in mangrove sediments. Appl Microbiol Biotechnol 89:1243-1254. https://doi.org/10.1007/s00253-0102929-0

Li JL, Nedwell DB, Beddow J, Dumbrell AJ, McKew BA, Thorpe EL, Whitby $C$ (2015) amoA gene abundances and nitrification potential rates suggest that benthic ammonia-oxidizing bacteria and not archaea dominate $\mathrm{N}$ cycling in the Colne Estuary, United Kingdom. Appl Environ Microbiol 81:159-165. https://doi.org/10.1128/AEM. 02654-14

Ling J, Lin XC, Zhang YY, Zhou WG, Yang QS, Lin LY, Zeng SQ, Zhang Y, Wang C, Ahmad M, Long LJ, Dong JD (2018) Community composition and transcriptional activity of ammoniaoxidizing prokaryotes of seagrass Thalassia hemprichii in coral reef ecosystems. Front Microbiol 9:7. https://doi.org/10.3389/fmicb. 2018.00007

Liu Y, Liu YZ, Ding YJ, Zheng JW, Zhou T, Pan GX, Crowley D, Li LQ, Zheng JF, Zhang XH, Yu XY, Wang JF (2014) Abundance, composition and activity of ammonia oxidizer and denitrifier communities in metal polluted rice paddies from South China. PLoS One 9: e102000. https://doi.org/10.1371/journal.pone.0102000

Martens-Habbena W, Berube PM, Urakawa H, de la Torre JR, Stahl DA (2009) Ammonia oxidation kinetics determine niche separation of nitrifying archaea and bacteria. Nature 461:976-979. https://doi.org/ 10.1038 /nature 08465

Martikainen P, Nurmiaho-Lassila EL (2011) Nitrosospira, an important ammonium-oxidizing bacterium in fertilized coniferous forest soil. Can J Microbiol 31:190-197. https://doi.org/10.1139/m85-037

Ochsenreiter T, Selezi D, Quaiser A, Bonch-Osmolovskaya L, Schleper C (2003) Diversity and abundance of Crenarchaeota in terrestrial habitats studied by $16 \mathrm{~S}$ RNA surveys and real time PCR. Environ Microbiol 5:787-797. https://doi.org/10.1046/j.1462-2920.2003. 00476.x

Ottosen LDM, Risgaard-Petersen N, Nielsen LP (1999) Direct and indirect measurements of nitrification and denitrification in the rhizosphere of aquatic macrophytes. Aquat Microb Ecol 19:81-91. https://doi.org/10.3354/ame019081

Pal L, Kraigher B, Brajer-Humar B, Levstek M, Mandic-Mulec I (2012) Total bacterial and ammonia-oxidizer community structure in moving bed biofilm reactors treating municipal wastewater and inorganic synthetic wastewater. Bioresour Technol 110:135-143. https:// doi.org/10.1016/j.biortech.2012.01.130

Park HD, Noguera DR (2007) Characterization of two ammoniaoxidizing bacteria isolated from reactors operated with low dissolved oxygen concentrations. J Appl Microbiol 102:1401-1417. https://doi.org/10.1111/j.1365-2672.2006.03176.x

Park BJ, Park SJ, Yoon DN, Schouten S, Sinninghe Damsté JS, Rhee SK (2010) Cultivation of autotrophic ammonia-oxidizing archaea from marine sediments in coculture with sulfur-oxidizing bacteria. Appl Environ Microbiol 76:7575-7587. https://doi.org/10.1128/AEM. 01478-10

Prosser JI, Nicol GW (2008) Relative contributions of archaea and bacteria to aerobic ammonia oxidation in the environment. Environ Microbiol 10:2931-2941. https://doi.org/10.1111/j.1462-2920. 2008.01775.x

Prosser JI, Nicol GW (2012) Archaeal and bacterial ammonia-oxidisers in soil: the quest for niche specialization and differentiation. Trends Microbiol 20:523-531. https://doi.org/10.1016/j.tim.2012.08.001

Purkhold U, Wagner M, Timmermann G, Pommerening-Röser A, Koops HP (2003) 16S rRNA and amoA-based phylogeny of 12 novel betaproteobacterial ammonia-oxidizing isolates: extension of the dataset and proposal of a new lineage within the Nitrosomonads. Int J Syst Evol Microbiol 53:1485-1494. https://doi.org/10.1099/ijs. 0.02638-0

Rotthauwe JH, Witzel KP, Liesack W (1997) The ammonia monooxygenase structural gene amoA as a functional marker: Molecular fine-scale analysis of natural ammonia-oxidizing populations. Appl Environ Microbiol 63:4704-4712. https://doi. org/10.1128/aem.63.12.4704-4712.1997

Rysgaard S, RisgaardPetersen N, Sloth NP (1996) Nitrification, denitrification, and nitrate ammonification in sediments of two coastal lagoons in Southern France. Hydrobiologia 329:133-141

Schleper C (2010) Ammonia oxidation: different niches for bacteria and archaea? ISME J 4:1092-1094. https://doi.org/10.1038/ismej.2010. 111

Schloss PD, Handelsman J (2005) Introducing DOTUR, a computer program for defining operational taxonomic units and estimating species richness. Appl Environ Microbiol 71:1501-1506. https://doi. org/10.1128/AEM.71.3.1501-1506.2005

Schloss PD, Westcott SL, Ryabin T, Hall JR, Hartmann M, Hollister EB, Lesniewski RA, Oakley BB, Parks DH, Robinson CJ, Sahl JW, Stres B, Thallinger GG, Van Horn DJ, Weber CF (2009) Introducing mothur: open-source, platform-independent, community-supported software for describing and comparing microbial communities. Appl Environ Microbiol 75:7537-7541. https://doi.org/10.1128/AEM.01541-09

Stahl DA, de la Torre JR (2012) Physiology and diversity of ammoniaoxidizing archaea. Annu Rev Microbiol 66:83-101. https://doi.org/ 10.1146/annurev-micro-092611-150128

Stamatakis A (2014) RAxML version 8: a tool for phylogenetic analysis and post-analysis of large phylogenies. Bioinformatics 30:13121313. https://doi.org/10.1093/bioinformatics/btu033

Stieglmeier M, Klingl A, Alves RJE, Rittmann SKR, Melcher M, Leisch N, Schleper C (2014) Nitrososphaera viennensis gen. nov., sp. nov., an aerobic and mesophilic, ammonia-oxidizing archaeon from soil and a member of the archaeal phylum Thaumarchaeota. Int J Syst Evol Microbiol 64:2738-2752. https://doi.org/10.1099/ijs.0. 063172-0

Sun FF, Zhang XL, Zhang QQ, Liu FH, Zhang JP, Gong J (2015) Seagrass (Zostera marina) colonization promotes the accumulation of diazotrophic bacteria and alters the relative abundances of specific bacterial lineages involved in benthic carbon and sulfur cycling. Appl Environ Microbiol 81:6901-6914. https://doi.org/10.1128/ AEM.01382-15

Sun DY, Tang XF, Zhao MY, Zhang ZX, Hou LJ, Liu M, Wang BZ, Klümper U, Han P (2020) Distribution and diversity of comammox nitrospira in coastal wetlands of China. Front Microbiol 11:589268. https://doi.org/10.3389/fmicb.2020.589268

Suzuki I, Dular U, Kwok SC (1974) Ammonia or ammonium ion as substrate for oxidation by Nitrosomonas europaea cells and extracts. J Bacteriol 120:556-558

Tal Y, Watts JEM, Schreier SB, Sowers KR, Schreier HJ (2003) Characterization of the microbial community and nitrogen transformation processes associated with moving bed bioreactors in a closed recirculated mariculture system. Aquaculture 215:187-202. https:// doi.org/10.1016/S0044-8486(02)00372-1

Taylor AE, Zeglin LH, Dooley S, Myrold DD, Bottomley PJ (2010) Evidence for different contributions of archaea and bacteria to the ammonia-oxidizing potential of diverse Oregon Soils. Appl Environ Microbiol 76:7691-7698. https://doi.org/10.1128/AEM.01324-10

Taylor AE, Zeglin LH, Wanzek TA, Myrold DD, Bottomley PJ (2012) Dynamics of ammonia-oxidizing archaea and bacteria populations and contributions to soil nitrification potentials. ISME J 6:2024 2032. https://doi.org/10.1038/ismej.2012.51

Thandar SM, Ushiki N, Fujitani H, Sekiguchi Y, Tsuneda S (2016) Ecophysiology and comparative genomics of Nitrosomonas mobilis Ms1 isolated from autotrophic nitrifying granules of wastewater treatment bioreactor. Front Microbiol 7:1869. https://doi.org/10. 3389/fmicb.2016.01869

Tourna M, Stieglmeier M, Spang A, Könneke M, Schintlmeister A, Urich T, Engel M, Schloter M, Wagner M, Richter A, Schleper C (2011) Nitrososphaera viennensis, an ammonia oxidizing archaeon from 
soil. Proc Natl Acad Sci U S A 108:8420-8425. https://doi.org/10. 1073/pnas. 1013488108

van Kessel MAHJ, Speth DR, Albertsen M, Nielsen PH, Op den Camp HJM, Kartal B, Jetten MSM, Lücker S (2015) Complete nitrification by a single microorganism. Nature 528:555-559. https://doi.org/10. 1038/nature16459

Wang HT, Su JQ, Zheng TL, Yang XR (2015) Insights into the role of plant on ammonia-oxidizing bacteria and archaea in the mangrove ecosystem. J Soils Sediments 15:1212-1223. https://doi.org/10. 1007/s11368-015-1074-x

Wang XM, Wang SY, Shi GS, Wang WD, Zhu GB (2019) Factors driving the distribution and role of AOA and AOB in Phragmites communis rhizosphere in riparian zone. J Basic Microbiol 59:425436. https://doi.org/10.1002/jobm.201800581

Waycott M, Duarte CM, Carruthers TJB, Orth RJ, Dennison WC, Olyarnik S, Calladine A, Fourqurean JW, Heck KLJ, Hughes AR, Kendrick GA, Kenworthy WJ, Short FT, Williams SL (2009) Accelerating loss of seagrasses across the globe threatens coastal ecosystems. Proc Natl Acad Sci U S A 106:12377-12381. https:// doi.org/10.1073/pnas.0905620106

Wessén E, Nyberg K, Jansson JK, Hallin S (2010) Responses of bacterial and archaeal ammonia oxidizers to soil organic and fertilizer amendments under long-term management. Appl Soil Ecol 45:193-200. https://doi.org/10.1016/j.apsoil.2010.04.003
Zarnoch CB, Hoellein TJ, Furman BT, Peterson BJ (2017) Eelgrass meadows, Zostera marina (L.), facilitate the ecosystem service of nitrogen removal during simulated nutrient pulses in Shinnecock Bay, New York, USA. Mar Pollut Bull 124:376-387. https://doi. org/10.1016/j.marpolbul.2017.07.061

Zhang JP, Liu B, Zhou XH, Chu JY, Li YM, Wang MY (2015a) Effects of emergent aquatic plants on abundance and community structure of ammonia-oxidising microorganisms. Ecol Eng 81:504-513. https://doi.org/10.1016/j.ecoleng.2015.04.029

Zhang Y, Chen LJ, Dai TJ, Sun RH, Wen DH (2015b) Ammonia manipulates the ammonia-oxidizing archaea and bacteria in the coastal sediment-water microcosms. Appl Microbiol Biotechnol 99:64816491. https://doi.org/10.1007/s00253-015-6524-2

Zheng YL, Hou LJ, Newell S, Liu M, Zhou JL, Zhao H, You LL, Cheng XL (2014) Community dynamics and activity of ammoniaoxidizing prokaryotes in intertidal sediments of the Yangtze estuary. Appl Environ Microbiol 80:408-419. https://doi.org/10.1128/AEM. 03035-13

Publisher's note Springer Nature remains neutral with regard to jurisdictional claims in published maps and institutional affiliations. 